ISSN: 0213-2060

DOI: https://doi.org/10.14201/shhme2019372133153

\title{
LAS FORMAS DEL PODER EN LA FEUDALIDAD TARDÍA. LAS TOMAS DE POSESIÓN EN EL SEÑORÍO DE LA IGLESIA DE SANTIAGO DE COMPOSTELA DURANTE EL SIGLO XV: DOMINIO, GESTO Y SIGNIFICACIÓN
}

\author{
The Forms of Power in Late Feudalism. The Takovers in the Lordship of the Church \\ of Santiago de Compostela during the $15^{\text {th }}$ Century: Domain, Gesture and Signification
}

Xosé M. SÁNCHEZ SÁNCHEZ

Depto. de Historia, Arte e Xeografía. Facultade de Historia. Universidade de Vigo. Campus Universitario As Lagoas. Pabellón 2, 1. a planta.E-32004 OURENSE. C. e.: xsanchez@uvigo.es

Recibido: 2019-07-11

Revisado: 2019-10-22

Aceptado: 2019-11-08

RESUMEN: Este artículo estudia los gestos y elementos rituales de las tomas de posesión bajomedievales como forma de transmisión del dominio, tanto directo como útil. Tomamos como objeto de análisis el señorío de la iglesia de Santiago de Compostela en el siglo $\mathrm{xv}$, un marco social y señorial que, sobre estos presupuestos, no había sido considerado hasta la fecha. Las formas y gestos del sistema feudal evidencian desde sus inicios ideas y concepciones. Estos procesos rituales llegan hasta la baja Edad Media, en un feudalismo tardío, mediatizados por los cambios que producen la expansión del fenómeno urbano y la contracción del siglo xIv. Tomando como cuerpo de fuentes la documentación catedralicia y episcopal compostelana del Cuatrocientos, editada e inédita, el estudio analiza y define el proceso gestual de la posesión sobre sus elementos simbólicos materiales y conceptuales.

Palabras clave: Feudalismo; Toma de posesión; Rito; Galicia; Baja Edad Media; Santiago de Compostela.

ABSTRACT: This paper studies the gestures and ritual elements of the late medieval takeovers as a form of domain transmission, both direct and useful. We take as an object of analysis the lordship of the church of Santiago de Compostela in the $15^{\text {th }}$ Century, a social and feudal framework that, on these assumptions, had not been considered to date. The forms and gestures of the feudal system show ideas and conceptions from the beginning. 
LAS FORMAS DEL PODER EN LA FEUDALIDAD TARDÍA. LAS TOMAS DE POSESIÓN EN EL SEÑORÍO 134 DE LA IGLESIA DE SANTIAGO DE COMPOSTELA DURANTE EL SIGLO XV: DOMINIO, GESTO...

These ritual processes reach the late Middle Ages, in a late feudalism, mediated by the changes produced by the expansion of the urban phenomenon and the contraction of the $14^{\text {th }}$ Century. Taking as sources the Cathedral and Episcopal documentation of the $15^{\text {th }}$ Century, published and unpublished, the study analyzes and defines the gestural process of possession over its material and conceptual symbolic elements.

Keywords: Feudalism; Takeover; Rite; Galicia; Low Middle Ages; Santiago de Compostela.

SUMARIO: 1 Referencias bibliográficas.

En la investigación del feudalismo la consideración de sus formas atiende a la propia feudalidad, sobre un sistema de representación simbólica que reafirma el poder ${ }^{1}$. El desarrollo gestual tiene poco de aleatorio y su significación es profunda desde los tiempos del feudalismo clásico en su expansión por la Europa Occidental ${ }^{2}$; son aquellos los «gestes symboliques dans la vie sociale» que definía J. Le Goff en atención al vasallaje ${ }^{3}$. Hacia la baja Edad Media las condiciones diferentes de espacios y contextos moldean un cambio en la gestualidad, midiendo la pervivencia de ciertas concepciones atenuadas por una sociedad distinta. El presente artículo se ocupará de las formas de la feudalidad tardía del último siglo medieval sobre la base del cambio y la continuidad, analizadas en uno de los procesos y documentos notariales de mayor significación simbólica y gestual en cuanto su contenido: las tomas de posesión. El tipo documental es común al territorio castellano en la baja Edad Media, tanto en lo general de sus formas como en una actio que recoge un cambio de titularidad. Pero, especialmente y aquí nuestro interés, muestran y describen un proceso de marcada dimensión ritual y simbólica que permite observar el mantenimiento de categorías de sentido feudal todavía vigentes, así como la gestualidad que ahora se les asocia.

Las caracterizaba Isabel Beceiro como «actos rituales que expresan la naturaleza del poder de una forma simbólica, que guarda similitudes con el vasallaje y la investidura feudal» ${ }^{4}$. Tales procesos reconocen públicamente la propiedad, el dominio y

1 Quintanilla Raso, M. a Concepción. «El orden señorial y su representación simbólica: ritualidad y ceremonia en Castilla a fines de la Edad Media». Anuario de Estudios Medievales, 1999, vol. 29, p. 844. En cuanto a comunicación simbólica en relación al feudalismo clásico a nivel general cf. Althoff, Gerd; Wiтtнöfт, Christiane y Duthoo, Aurélie. «Les services symboliques entre dignité et contrainte». Annales. Histoire, Sciences Sociales, 2003, vol. 58, n. ${ }^{\circ}$ 6, pp. 1293-1318.

2 «La sociedad bajomedieval castellana estaba ritualizada en diversos aspectos, no como un síntoma de escasa cultura, sino como manifestación de la integración de unos valores que respaldaban la práctica jurídica». Puñal Fernández, Tomás. "Análisis documental de los rituales de posesión en la Baja Edad Media». Espacio, Tiempo y Forma. Serie III, Historia Medieval, 2002, vol. 15, p. 118.

3 Le Goff, Jacques. "Gestes symboliques dans la vie sociale. Les gestes de la vassalité». En Simboli e simbologia nell'Alto Medioevo. Atti (dal 3 al 9 aprile 1975). Spoleto: Fondazione CISAM, 1976, pp. 679-779.

4 Beceiro Pita, Isabel. «El escrito, la palabra y el gesto en las tomas de posesión señoriales». Studia Historica. Historia Medieval, 1994, vol. 12, p. 53. Señala Carlos Estepa el papel de la ceremonia en cuanto al desarrollo del feudalismo, así como el reconocimiento a través de un acto ritual. Estepa Díez, Carlos. "Notas sobre el feudalismo castellano en el marco historiográfico general». En SArasa Sánchez, Esteban y SERrano 
LAS FORMAS DEL PODER EN LA FEUDALIDAD TARDÍA. LAS TOMAS DE POSESIÓN EN EL SEÑORÍO DE LA IGLESIA DE SANTIAGO DE COMPOSTELA DURANTE EL SIGLO XV: DOMINIO, GESTO... XOSÉ M. SÁNCHEZ SÁNCHEZ

la derivación de derechos desgajados y enajenados, no renunciados sino delegados a través de un desarrollo que marca la presencia de lo conceptual en lo ritual ${ }^{5}$. La medida gestualidad busca fijar el acontecimiento en la retina de los asistentes a través de un mensaje eminentemente visual ${ }^{6} \mathrm{y}$ su estudio permite definir de primera mano el «aparato conceptual aceptado por individuos y colectividades, y puesto en práctica en sus pensamientos y en sus actuaciones» de la sociedad bajomedieval ${ }^{7}$. El objeto no serán meramente las formas sino lo que transmiten del fondo: la presencia sobre tales gestos de conceptos feudales que se demuestran todavía operativos. Unos gestos definidos y profundos que, siguiendo la línea feudal, se constituyen en "generadores de derechos" ${ }^{8}$.

La cuestión ha tenido ya su atención en la generalidad peninsular en una línea de investigación que rebasa el acontecimiento para profundizar en la mentalidad colectiva y el espacio simbólico, pero no ha sido especificado para uno de los territorios más fuertemente señorializados: el reino de Galicia ${ }^{10}$. Igual que en otros espacios peninsulares la complicación de las estructuras sociales con el desarrollo del mundo urbano, unida a la fuerte presencia del poder señorial laico y eclesiástico de marcada tendencia en el siglo $\mathrm{XV}$, organiza un perfecto campo de estudio. La amplitud del reino y de las condiciones señoriales me conducen a localizar el marco de análisis sobre el principal espacio territorial delimitado en la tradición señorial: el señorío eclesiástico de la iglesia de Santiago de Compostela ${ }^{11}$. Territorialmente toma forma desde los siglos XI-XII en la llamada Tierra

Martín, Eliseo (eds.). Estudios sobre señorio y feudalismo. Homenaje a Julio Valdeón. Zaragoza: Institución Fernando el Católico, 2010, p. 80.

5 Del valor probatorio de las escrituras para la Galicia bajomedieval en el marco de una «judicialización de la sociedad bajomedieval»: Ríos RodríGuez, María Luz. «El valor de las escrituras: resolución de conflictos entre señores y campesinos en la Galicia bajomedieval». Edad Media. Revista de Historia, 2010, vol. 11, p. 156.

6 Beceiro Pita, «El escrito, la palabra y el gesto», p. 71.

7 Quintanilla Raso, «El orden señorial», p. 844.

8 Puñal Fernández, «Análisis documental», p. 119.

9 Recogía Concepción Quintanilla el interés que ha suscitado este tipo documental como fuente para el espacio castellano más allá de lo factual a partir de los años 80. Quintanilla RAso, «El orden señorial», p. 846. Destaca especialmente la primera aproximación de Isabel Beceiro en 1984, más orientada a la gestualidad feudal laica y de los pleitos-homenaje, con presencia de lo jurisdiccional: Beceiro Pita, Isabel. «La imagen del poder feudal en las tomas de posesión bajomedievales castellanas». Studia Historica. Historia Medieval, 1984, vol. 2, pp. 157-162. Hemos de añadir en atención principalmente al señorío laico: Beceiro Pita, «El escrito, la palabra y el gesto». Resume de manera más reciente: Miceli, Paola Alejandra. «Gestualidad corporal y estructura formular en los rituales de posesión en Castilla (siglo xv)». Calamus. Revista de la Sociedad Argentina de Estudios Medievales, 2019, vol. 3, pp. 38-48.

10 Acerca del proceso de feudalización gallega cf. Portela Silva, Ermelindo. «La articulación de la sociedad feudal en Galicia». En En torno al feudalismo hispánico. I Congreso de Estudios Medievales. Ávila: Fundación Sánchez-Albornoz, 1989, pp. 331-340; Portela Silva, Ermelindo y Pallares Méndez, María del Carmen. De Galicia en la Edad Media: sociedad, espacio y poder. Santiago de Compostela: Consellería de Relacions Institucionais e Portavoz do Goberno, 1993; Pallares, María Carmen y Portela, Ermelindo. «De la villa del siglo IX a la aldea del siglo xıII. Espacio agrario y feudalización en Galicia». Asturiensia Medievalia, 1995-1996, vol 8, pp. 47-69.

11 Señalaba ya Isabel Beceiro la presencia de este tipo de fuentes para el señorío episcopal. Beceiro PITA, «El escrito, la palabra», p. 54. 
LAS FORMAS DEL PODER EN LA FEUDALIDAD TARDÍA. LAS TOMAS DE POSESIÓN EN EL SEÑORÍO DE LA IGLESIA DE SANTIAGO DE COMPOSTELA DURANTE EL SIGLO XV: DOMINIO, GESTO...

de Santiago ${ }^{12}$, un espacio heterogéneo sobre el que la administración eclesiástica, con el arzobispo a la cabeza, extendía sus formas de gestión señorial, económica y administrativa desde la capacidad jurisdiccional compostelana ${ }^{13}$.

Partiendo de una línea conceptual de origen bien anterior ${ }^{14}$, en 1467 continúan vivas las referencias a la feudalidad en el territorio compostelano. Cuando se rectifican los dineros e seruentias a pagar anualmente a la institución catedralicia compostelana en las feligresías de San Pedro de Cervás, Santa María da Lubre y San Vicente de Caamouco, se relaja el pago por seruiçoos e vasallaje e sennorio a la par que se veta la posibilidad de enfeudaren a cabaleyro nen a escudeyro nen a ome ningun poderoso ${ }^{15}$. No trataremos los posibles restos del homenaje feudovasallático ${ }^{16}$ ni las acepciones del término vasallo en el feudalismo castella$\mathrm{no}^{17}$, que considera la «generalidad de los moradores de un lugar de seńorío respecto del señor, con relativo olvido del sentido originario de ese término» ${ }^{18}$. Pero la importancia en la utilización del término «enfeudar» y de la propia actio no es baladí. Remite, en lo lejano, al propio acto simbólico que definía G. de Valdeavellano para "poner al vasallo o feudatario en posesión del objeto del 'feudo'»", vetando aquí una posible enajenación ulterior de

12 Acerca de la configuración territorial del señorío compostelano cf. PÉrez Rodríguez, Francisco Javier. «Santiago, espacio de poder: la Tierra de Santiago y su evolución (s. XI-XIv)». En Estepa Díez, Carlos; Martínez Sopena, Pascual y Jular Pérez-Alfaro, Cristina. El Camino de Santiago. Estudios sobre peregrinación y sociedad. Madrid: Fundación de Investigaciones Marxistas, 2000, pp. 33-76.

13 VÁzquez Bertomeu, Mercedes. "La escritura y su uso: la mesa arzobispal compostelana a finales del siglo XV». Anuario de Estudios Medievales, 2001, vol. 31, n. ${ }^{\circ}$ 1, pp. 403-405.

14 Por ejemplo, en la transmisión de los derechos de terrarías por parte de la prelatura a segmentos de la aristocracia laica en los siglos XIII y XIV, y estableciendo a los nuevos poseedores que bos ajam e recebam por sennor e terreiro delas, aunque, como señala Marta González, se «ejerza ese señorío por delegación del prelado compostelano y su iglesia». González VÁzquez, Marta. El arzobispo de Santiago: una instancia de poder en la Edad Media (1150-1400). Santiago de Compostela: Seminario de Estudios Gallegos, 1996, p. 161.

15 Archivo-Biblioteca de la Catedral de Santiago (en adelante ACS), CF 26, Tumbo G, fols. 47v-48r.

16 Concepción Quintanilla desarrolla especialmente lo gestual y su sentido en "El orden señorial», pp. 865-869.

17 Rodríguez Llopis hacía hincapié en la dificultad para la definición del término en la documentación castellana, más en la línea del marco de las relaciones de producción que en lo institucional: «estamos, por tanto, ante una acepción de la palabra 'vasallo' que ha unido a sus connotaciones jurídicas otras de índole socio-económica. Además, el concepto de vasallo queda desprovisto de sus rasgos esenciales al no encontrarse inmerso en las relaciones vasalláticas propias de la clase feudal, impregnándose de los caracteres básicos de las relaciones sociales de producción existente». Rodríguez Llopis, Miguel. «Las tomas de posesión bajomedievales y la ideología feudal. La incorporación de la tierra de Alarcón al marquesado de Villena». En Congreso de historia del señorio de Villena. Albacete 23-26 octubre 1986. Albacete: Instituto de Estudios Albacetenses, 1987, pp. 349-356.

18 Martín Prieto, Pablo. «Las tomas de posesión de las villas del infantado de Huete por el condestable Álvaro de Luna en 1442». Anuario de Estudios Medievales, 2013, vol. 43, n. ${ }^{\circ} 2$, p. 721 . Valdeavellano lo había extendido ya a "relaciones de dependencia personal que no tenían carácter noble». GARCía DE VALDEAvellano, Luis. Curso de Historia de las Instituciones españolas. Madrid: Alianza Editorial, 2. ${ }^{a}$ reimpr., 1986, p. 383. En el seńorío compostelano el uso del término en la documentación parece acercarse a esta forma en cuanto a los cotos seńoriales de la iglesia de Santiago: «es uno de los capitulares, prestimoniario o tenenciero, quien se erige en el verdadero señor feudal del espacio acotado y sólo a él -en representación, eso sí, de la corporación- a quienes los couteiros, sus vasalos, deben someterse». PÉrez Rodríguez, Francisco Javier. El dominio del cabildo catedral de Santiago de Compostela en la Edad Media (Siglos XII-XV). Santiago de Compostela: Tórculo Artes Gráficas, 1994.

19 García de Valdeavellano, Curso de Historia, p. 371. 
LAS FORMAS DEL PODER EN LA FEUDALIDAD TARDÍA. LAS TOMAS DE POSESIÓN EN EL SEÑORÍO DE LA IGLESIA DE SANTIAGO DE COMPOSTELA DURANTE EL SIGLO XV: DOMINIO, GESTO... XOSÉ M. SÁNCHEZ SÁNCHEZ

derechos señoriales ahora transmitidos ${ }^{20}$. El sentido de lo simbólico que llega hasta el siglo xv estaba ya presente en la infeudación clásica, sobre símbolos de acción, al poner en las manos del vasallo un símbolo que le era devuelto, o símbolos de objeto, en la entrega de un objeto representativo del conjunto ${ }^{21}$. Como siempre, la dimensión de la significación en la mentalidad colectiva, asociada ahora a formas sociales y en relacion al poder político, encuentra su acomodo en la larga duración y el cambio lento. La gestualidad que marca estos actos públicos viene ya de tiempo anterior y se mantiene durante todo el siglo XV en plena forma.

Las fuentes que desgranamos permiten manejar dos conceptos bien conocidos de la feudalidad plena y que, con ciertos cambios, continúan siendo operativos para el noroeste: dominio directo y dominio útil. La diferenciación que marcaban las Partidas de Alfonso X, especialmente en la ley Qué cosa es señorio e quantas maneras son del sobre una división bipartita a mayores del señorío regio, continúa aquí vigente: por una parte el poder que ome ha en las cosas muebles, o raya deste mundo en su vida, e despues de su muerte passa a sus herederos o a aquellos a quien la enagenasse mientras biuiesse; y por otra el poderio que ome ha en fruto, o en renta de algunas cosas en su vida, o a tiempo cierto ${ }^{22}$. El fundamento es la posesión de persona o institución sobre unos bienes, adquiridos o heredados, y por tanto su disposición total sobre ellos, de la cual puede desligar el disfrute y delegarlo o enajenarlo a cambio de renta. Este uso podía ser de labradores o yugueros o los que tienen arrendadas o alogadas cosas agenas, como quier que ellos sean apoderados de la tenencia dellas. Pero la verdadera possession es de aquellos en cuyo nombre tienen el heredamiento; e por ende quanto tiempo quier que ellos las tuuiesen assi, no ganarian el señorio por ello ${ }^{23}$.

Ambos dominios, directo y útil, llegan hasta la última centuria medieval en la larga evolución del feudalismo clásico. En Galicia, igual que en otros espacios, lo hacen sobre el desarrollo de los grandes dominios territoriales altomedievales culminados en los señoríos jurisdiccionales de los siglos XI-XII. El cambio en sociedad y economía irá moldeando el sistema sobre presupuestos diferentes, especialmente tras la contracción del siglo XIV. Al hilo se solapan propiedad y jurisdicción en manos diferentes, evidenciando la propia diferencia de los conceptos; resultaba especialmente claro en la tenencia de fortalezas, con la existencia en el siglo XIV, como aclaraba Marta González, de «fortalezas no arzobispales, pero situadas en señorío compostelano» ${ }^{24}$. En el desarrollo del Cuatrocientos no solo se mantienen ambos tipos de dominio como conceptos operativos, sino que, en el caso de espacios productivos y de habitación, parecen incluso mejor delimitados ${ }^{25}$.

20 La línea es la de un feudalismo de extensión ultrapirenaica que verá su asentamiento en un régimen señorial de modelo feudal clásico en el espacio castellano. Martín Prieto, «Las tomas de posesión», p. 720.

21 García de Valdeavellano, Curso de Historia, p. 371.

22 Partida III, título XXVIII, ley I, en LópeZ, Gregorio (ed.). Las Siete Partidas del Sabio Rey don Alonso el nono. Salamanca: Impr. Andrea de Portonariis, 1555, vol. 2, fol. 172r. Lo que Tomás Puñal ha definido como «una propiedad legal o eminente, como posesión fundamentada en derecho, auténtica y verdadera [...] y una propiedad útil, en cuanto al disfrute de un bien, pero del que no se tiene la propiedad verdadera, con lo que se genera una contraprestación económica». Puñal Fernández, «Análisis documental», p. 115.

${ }_{23}$ Partida III, título XXX, ley V. López, Las Siete Partidas, vol. 2, fol. 155v.

24 González VÁzquez, El arzobispo de Santiago, p. 190.

25 Propiedad y tenencia de castillos parece confundirse en el marco compostelano de manera que «solo en ciertos casos testigos cualificados son capaces de discernir entre tener una fortaleza por suia propia o por la Iglesia». Ibidem, p. 191. 
LAS FORMAS DEL PODER EN LA FEUDALIDAD TARDÍA. LAS TOMAS DE POSESIÓN EN EL SEÑORÍO DE LA IGLESIA DE SANTIAGO DE COMPOSTELA DURANTE EL SIGLO XV: DOMINIO, GESTO...

Cuando en 13 de marzo de 1455 Juan Ares, luminario de la capilla de San Bieito do Campo en la ciudad de Santiago, toma posesión de una casa en la calle de Vilourente se especifica que el inmueble ha de quedar en propiedad de María Bernáldez y, a su muerte, pasará a la luminaria de dicha capellanía. La institución busca acelerar el proceso con ella para que conosçendo o feito da verdade, dese a posison da dita casa ao dito lume e a elles por nome del, reteendo a morada durante os seus dias ${ }^{26}$. Es de manera genérica, pero clara, la separación entre propiedad (posison), núcleo del dominio directo, y disfrute (morada) del útil ${ }^{27}$.

La transferencia de ambos dominios sobre un determinado bien, o la de uno de ellos, es variable en sus condiciones. Un inmueble, una unidad de explotación, el disfrute de una casa como nueva voz en un arriendo... son elementos susceptibles de ser tanto traspasados de manera permanente como cedidos a un tercero de forma temporal. En el conjunto del territorio gallego la venta o donación es la vía más común que toma la transmisión en el dominio directo, permanente, propietario, mientras que el foro o arriendo es la que suele adoptar la cesión del dominio útil, a cambio de renta y en una enajenación de temporalidad variable ${ }^{28}$. Desde ahí la toma de posesión es un acto simbólico en la explicitación del poder seńorial ${ }^{29}$. La transmisión de dominios cobra cuerpo legal sobre su ajuste al derecho, pero ahora también sobre la culminación pública en una gestualidad definida ${ }^{30}$. La validación de ese cambio de titularidad se rubrica con un proceso ritual de afirmación de carácter público que se mantiene en el territorio compostelano hasta finales del siglo xv. Cuando en 21 de noviembre de 1494 el cambiador en la ciudad de Santiago Gonzalo de Covas se dispone a tomar posesión del pazo y propiedades de Noente, por herencia de su suegra, pone especial interés en que esté presente el escudero

26 Fernández de Viana y Vieites, José Ignacio. El tumbillo de San Bieito do Campo (Santiago). Granada: Universidad de Granada, 1995, doc. 29, p. 83.

27 La jurisdicción ha trascendido a otra esfera. En el siglo xv el ámbito señorial, jurisdiccional, el dominio eminente, se ha escindido ya a través de una evolución política en tránsito desde hacía tiempo al Estado moderno y se mantiene a medias entre las instituciones tardo-feudales y la monarquía. Es elemento central y con presencia en otros actos ceremoniales relativos al señorío laico. Un derecho que en cualquier caso no funciona a nivel intermedio sino de disfrute propiamente señorial, aquí de la Iglesia de Santiago. Se desliga el dominio directo, el que posesiona, y de él a su vez el útil, que en ocasiones se delega. Quintanilla Raso, «El orden señorial», p. 860; Martín Prieto, «Las tomas de posesión», pp. 720-721.

28 Acerca del foro: Ríos Rodríguez, María Luz. Relaciones contractuales agrarias en la Galicia medieval: los orígenes del foro (1150-1350). Santiago de Compostela: Universidade de Santiago de Compostela, 1991.

29 Quintanilla Raso, «El orden señorial», p. 845. La significación de lugares en determinados actos dentro de la materialización del poder en el noroeste es conocida, destacando como objeto más reciente en la historiografía el de las asambleas altomedievales gallegas estudiadas por Andrade Cernadas; aquí y en cuanto al proceso "partes del mismo, como los juramentos, tenían que celebrarse, necesariamente, en recintos eclesiásticos y cuanto más significativo fuese el templo podría considerarse que sería como si el juramento ganase un plus de ritualidad y sacralidad». Andrade Cernadas, José Miguel. «Baños, claustros y piedras: una aproximación a los escenarios de las asambleas judiciales en la Galicia altomedieval». Studia Historica. Historia Medieval, 2018, vol. 36, n. ${ }^{\circ}$ 1, p. 21.

30 «El hecho de poseer algo, independientemente de su formulación legal, llevaba al hombre bajomedieval a realizar una serie de actos rituales, en cuanto se repiten sistemáticamente, con el fin de ratificar un determinado tipo de posesión, que previamente había sido justificada mediante derecho, a través de un documento dispositivo con plena validez legal». Puñal Fernández, "Análisis documental», p. 116. 
LAS FORMAS DEL PODER EN LA FEUDALIDAD TARDÍA. LAS TOMAS DE POSESIÓN EN EL SEÑORÍO DE LA IGLESIA DE SANTIAGO DE COMPOSTELA DURANTE EL SIGLO XV: DOMINIO, GESTO... XOSÉ M. SÁNCHEZ SÁNCHEZ

Nuno Álvarez, que le queria quitar e mouer del dicho logar, y solicita al alguacil que lo llame y traiga al acto. El mismo interés que tiene el escudero en no asistir, pues cuando van a buscarlo no se encuentra ya en su casa, alegando su esposa que había esperado fasta la ora de yantar, et que des que viera que non llegara que se fuera camino de Riba d'Auia a vna vendimia que tenia de faser ${ }^{31}$.

Esta gestualidad no se extiende a aposentamientos o confirmaciones que no implican cambios en la titularidad de dominios. Cuando en 2 de enero de 1407, y tras pleito a su favor con un tal Diego Fernández, el miembro de la oligarquía compostelana Pedro Leiteiro se apodera de una renta de ocho fanegas de pan sobre la leira de Figueira el proceso de aposentamiento consiste en una simple lectura pública. No hay aquí transmisión de ningún tipo más que un pago que se asienta y reconoce, y por ello la gestualidad carece hasta cierto punto de importancia ${ }^{32}$.

Todo ello da lugar a un tipo documental muy concreto, constituido en acta que fija por escrito el ritual de posesión ${ }^{33}$, por el cual el nuevo poseedor evidencia a quien lo quiera ver el cambio producido ${ }^{34}$; de ahí que como fuente documental acompañe generalmente a la actio que desarrolla el cambio de titularidad. Pueden observarse igualmente en relación a señoríos laicos ${ }^{35}$, aunque parecen predominar entre las instituciones catedralicias gallegas durante los siglos XIV y $\mathrm{XV}^{36}$. En lo compostelano han de incluirse aquellos documentos que los notarios de la Tierra de Santiago elaboraban en el marco de la «adquisición y gestión del patrimonio inmobiliario», tal y como define Mercedes Vázquez Bertomeu en cuanto a los denominados «actos particulares» ${ }^{37}$. Uno más de entre la rica variedad documental y dinamismo en lo escritorio y notarial durante la baja Edad Media toma forma en la principal cabeza del señorío eclesiástico gallego ${ }^{38}$.

31 ACS, P001, fol. 125r-v.

32 Ya en su primera aproximación al tema Isabel Beceiro señalaba la ausencia de ritualidad específica y gestualidad en cuanto a la toma de posesión de rentas. BeCEIro PitA, «La imagen del poder feudal», p. 162.

33 No me dedicaré a la forma diplomática o de la relación con el ámbito y desarrollo de lo escritorio. Cf. Beceiro Pita, «El escrito, la palabra», pp. 56-58 y Puñal FernándeZ, «Análisis documental», pp. 118-119 y 124-126, especialmente las minutas que desarrolla de la toma de posesión de majuelos, casas y solares de casa.

34 Se ha relacionado su sentido con el propio rito feudal de vasallaje a cambio del feudo: «el ceremonial constaba de una serie de ritos que, como en el caso de las transacciones, vienen a ser también la manifestación de una posesión, en este caso referida a la libre disposición de la voluntad del vasallo por parte del señor». Ibidem, p. 118.

35 Caso de la toma de posesión por Suero Gómez en 1450 de diversas feligresías concedidas por el arzobispo Rodrigo de Luna. Archivo Histórico Diocesano de Santiago, Leg. 45, fols. 110-115.

36 Cf. López Carreira, Anselmo. Documentos do arquivo da catedral de Ourense: (1289-1399). Santiago de Compostela: Consello da Cultura Galega, 2016, docs. 200 y 352. Portela Silva, María José. Documentos da catedral de Lugo, século XIV. Santiago de Compostela: Consello da Cultura Galega, 2007, docs. 444, 446, 450 y 573.

37 La propia investigadora caracteriza el tipo documental como «profundamente ritual». VÁzQUEZ Bertomeu, Mercedes. Notarios, notarías y documentos en Santiago y su tierra en el siglo XV. Sada-A Coruña: Seminario de Estudos Galegos, 2001, pp. 70-71. Acerca de la producción documental y sus formas en este espacio territorial cf. VÁzquez Bertomeu, Mercedes. «La audiencia arzobispal compostelana en el s. xv: introducción a su estudio diplomático». Cuadernos de Estudios Gallegos, 1998, vol. 45, pp. 9-29.

38 Sobre esta base, en lo escritorio y notarial, dando cobijo a estas tomas de posesión, se documenta una relativamente amplia riqueza en cuanto a los protagonistas de lo escrito y penetración social, la variedad de tipos en la producción y la multiplicidad de espacios vinculados en la ciudad. VÁzquez Bertomeu, 
LAS FORMAS DEL PODER EN LA FEUDALIDAD TARDÍA. LAS TOMAS DE POSESIÓN EN EL SEÑORÍO 140 DE LA IGLESIA DE SANTIAGO DE COMPOSTELA DURANTE EL SIGLO XV: DOMINIO, GESTO...

Más allá de la estructura diplomática que pueda presentar, de manera general el proceso se construye en dos esferas: la propiamente material como forma y certeza del aposentamiento sobre el contacto físico con los espacios; y la simbólica, en torno a objetos que materializan el derecho ejercido sobre el lugar o bien, generalmente las llaves o, en el caso de espacios productivos, elementos naturales que encarnan el conjunto. Una u otra tienen mayor o menor peso en función del caso, pero alguna ha de estar siempre presente.

Ya en lo concreto las tomas de posesión en el señorío compostelano del Cuatrocientos se realizan sobre una gestualidad bien definid ${ }^{39}$. La definición general marca cuatro momentos: presentación del beneficiario ante el bien/espacio del que se toma posesión, con declaración pública de la cesión; la toma de posesión del dominio directo a través de la apropiación física de elementos, reforzada por la declaración oral; la derivación, si procede, del dominio útil, nuevamente a través del proceso gestual, simbólico y verbal; y una petición y realización de testimonio notarial en refrendo de todo el procedimiento. Se repiten estos momentos tanto en las tomas de posesión de inmuebles como en las de espacios productivos de diversa entidad, aunque unos u otros pueden variar su fuerza o presencia.

Todo se inicia de manera general declarando la llegada al lugar del nuevo poseedor, aunque todavía no aposentado, haciendo exposición pública de la actio que ha derivado en el cambio de titularidad ${ }^{40}$. La explicación pública puede ser más o menos elaborada, pero todas y cada una de las fuentes consultadas abren con referencia al contexto en que la transmisión se ha producido ${ }^{41}$. En ocasiones se detalla la cuestión mostrando físicamente los documentos de venta o traspaso, pudiendo llegar a lectura en voz alta. Aquella posesión de 1455 por Juan Ares se iniciaba declarando que la difunta María Vázquez fesera seu testamento en que posera huun legato e clausola que dezia asi, para dar paso a la lectura ${ }^{42}$. Vendría a corresponderse con la "presentación de títulos justificatorios» que definía Beceiro Pita para las posesiones en el señorío laico ${ }^{43}$. Vázquez Bertomeu señalaba, para el siglo Xv, que «este modelo de acercamiento se caracteriza por la presencia las más de las veces de un intermediario y por llevar consigo con frecuencia procesos en los que

Mercedes. «Santiago en el siglo xv: protagonistas, usos y espacios de la escritura». Signo. Revista de Historia de la Cultura Escrita, 2004, vol. 13, p. 9.

39 Señalaba Concepción Quintanilla la necesidad de interpretar estos procesos sobre una «teoría del gesto, partiendo de un concepto amplio, en el que se da cabida a movimientos, posiciones, palabras y, naturalmente, objetos, y en la que la gestualidad aparece entendida en su doble dimensión de eficacia práctica y simbólica». Quintanilla Raso, «El orden señorial», p. 857.

40 El «escenario» es el lugar donde se ubica el objeto de la transferencia, lejos de la significación pública y política de edificios de entidad como las fortalezas. Quintanilla Raso, «El orden señorial», p. 854. Tenía especial imagen política en el término compostelano el castillo de Rocha Forte. Sánchez Sánchez, Xosé M. «La fortaleza de Rocha Forte como símbolo del poder político del arzobispado de Santiago de Compostela en la Galicia medieval (siglos XIII-Xv)». Castillos de España. Publicación de la Asociación Española de Amigos de los Castillos, 2012, vol. 164-166, pp. 68-76.

${ }_{41}$ No abundaremos todas las citas, dada la generalidad. Cf. por ejemplo ACS, CF 29, Tumbo E, fol. $10 \mathrm{v}$.

42 Fernández de Viana y Vieites, El tumbillo de San Bieito, doc. 29, p. 83.

43 Beceiro Pita, «El escrito, la palabra», p. 59. 
LAS FORMAS DEL PODER EN LA FEUDALIDAD TARDÍA. LAS TOMAS DE POSESIÓN EN EL SEÑORÍO DE LA IGLESIA DE SANTIAGO DE COMPOSTELA DURANTE EL SIGLO XV: DOMINIO, GESTO... XOSÉ M. SÁNCHEZ SÁNCHEZ

el oído y la vista tienen un protagonismo fundamental» ${ }^{44}$. Es la verbalización de una disposición anterior, de la que ahora dejan constancia, origen del acto que se prepara y cuyo conocimiento es obligado ${ }^{45}$.

Sobre esta base el momento que ocupa una mayor carga simbólica en todo el proceso es la propia transmisión del dominio y la representación alegórica de la voluntad del nuevo poseedor sobre su propiedad; lo que Concepción Quintanilla vendría a denominar «la puesta en escena» ${ }^{46}$. Se mantiene de manera general en Galicia lo determinado como "facultades de tipo general» por Isabel Beceiro en el conjunto castellano en cuanto a las «manifestaciones de derecho de uso» ${ }^{47}$. La acción del nuevo depositario del dominio directo toma forma en un contacto físico con el bien que es recibido, así como en el ejercicio de su albedrío sobre él como nuevo poseedor, principalmente a través del cierre y apertura de puertas, el paseo por la casa o echando fuera del inmueble al antiguo beneficiario $^{48}$. Esa toma de posesión de 1455 se continúa con esta gestualidad propia y María Bernáldez abreu a porta da dita casa e poso dentro ao luminario: es ella, la anterior poseedora, la que abre la puerta y, acompañando adentro al nuevo, culmina la transferencia. Este es uno de los sentidos principales de la toma de posesión, señalados ya por Isabel Beceiro, y válido tanto para los procesos laicos como eclesiásticos: «marcar la ruptura con la situación anterior y plasmar una realidad nueva» ${ }^{49}$.

Las posesiones de inmuebles urbanos muestran un procedimiento fundamentado en el recorrido físico del nuevo poseedor por el inmueble y en la materialización en las llaves como objeto destacado. Cuando en 23 de enero de 1478 Teresa Martínez renuncia al foro que tiene del cabildo sobre unas casas en la calle de la Conga, en Compostela, los canónigos Andrés de Trabazos y Juan García en representación de la institución toman posesión nuevamente de la propiedad en recuperación del dominio útil. La renuncia al uso y disfrute trae consigo la vuelta a un estado anterior a la disociación de dominios; y la institución poseedora de ambos, la catedral compostelana, toma de nuevo posesión en muestra pública. La referencia documental resulta relativamente detallada y permite seguir el proceso. Se declara que:

entraban e entraron dentro das ditas casas e que tomaban e reçebian e tomaron e reçeberon a posyson das ditas casas por andamento de pees e tomando en suas maaos as chabes delas. E çerraron e fecharon as portas das ditas casas e lebaron as ditas chabes en seu poder. E diseron que de conmo tomaban e reçebian e tomaron e reçeberon a dita posyson paçificamente e sen contradita alguna pidian e pediron a min o dito notario que lles lo dese ${ }^{50}$.

En lo material el aposentamiento físico se desarrolla con la entrada a la propiedad poseída y el ejercicio de la voluntad del poseedor, que por andamento de pees camina por

44 Esta forma en cuanto a la transmisión de lo escrito no es nueva en el señorío compostelano, sino que extiende ahora convenciones presentes con anterioridad. VÁzQUeZ BertomeU, «Santiago en el siglo XV», p. 15.

45 Ibidem, pp. 21-22.

46 Quintanilla Raso, «El orden señorial», p. 857.

47 Beceiro Pita, «El escrito, la palabra», p. 78.

48 Tomás Puñal las definía como características, todas ellas aquí presentes aunque con ciertas variaciones quizá por lo tardío del momento. Puñal FernándeZ, «Análisis documental», p. 128.

49 Beceiro Pita, «El escrito, la palabra», p. 72.

so ACS, CF 26, Tumbo G, fol. 61v. 
LAS FORMAS DEL PODER EN LA FEUDALIDAD TARDÍA. LAS TOMAS DE POSESIÓN EN EL SEÑORÍO DE LA IGLESIA DE SANTIAGO DE COMPOSTELA DURANTE EL SIGLO XV: DOMINIO, GESTO...

donde le place en su propiedad ${ }^{51}$. Al cierre de las puertas se ańade el guardado de las llaves, que da forma a la voluntad de mantener el espacio para sí controlando cualquier acceso: la voluntad del nuevo poseedor se hace no solo en sino sobre el espacio. Se finaliza con el reconocimiento público oral de la recepción y toma de posesión por los tomadores y con la certificación jurídica por testimonio notarial. El modelo, con algunas variaciones, es general en todo el siglo. En 13 de octubre de 1462 el cambiador Juan de Campo toma posesión de las casas que había comprado en la ciudad de Santiago y reçebeu o jur e posison da dita casa, real e autual e corporal, andando e paseandose por la dita casa a jur de paz e sen contradita alguna que ende lle fose feyta por persona alguna, e çerrando as portas dela, leuando as chaues en seu poder ${ }^{52}$.

Cuando el objeto de posesión es una casa con propiedad adyacente, ya sea en la ciudad o en un entorno rural, parecen mostrarse procesos más elaborados y elocuentes en la gestualidad simbólica. Los principales conjuntos son aquí las heredades y casales, que conjugan espacios de residencia con otros circundantes de cultivo y recolección. En la toma de posesión que hace el zapatero García Amores en 12 de febrero de 1456 sobre las propiedades que había comprado en el lugar de Cavada, feligresía de Santa María de Páramos, se posesiona entrando en la casa y çarrando as portas ${ }^{53}$. Y la que el mismo hace en 16 de febrero de 1470 en San Miguel de Cabana recoge su entrada dentro de las ditas casas [...] deytando maao do colmo de sobre as portas das ditas casas, abrindo as ditas portas delas et deytando maao de pedra et barro ${ }^{54}$. El contacto físico se destaca aquí especialmente en el tacto del poseedor, propietario del espacio y detentador ahora del dominio directo, con su mano sobre la puerta, la tierra y el barro evidenciando la posesión y aposentamiento sobre lo que ya es suyo.

El ejercicio de la voluntad del nuevo poseedor parece tomar la extensión o forma que este quiera darle. Cuando en 18 de abril de 1482 Juan Calviño, racionero compostelano, toma posesión del casal de Donego, en el lugar de Iglixoa, feligresía de San Breixome de Solans y en el que vivía el labrador Juan Fernández, entrou enna casa do dito casal et acendeu lume dentro dela, et deytou fora da dita casa a Moor Fernandez, moller do dito Juan Fernandez, et çerrou as portas da dita cassa de sua maao et tomou colmo de cima dela et da rama das aruores ${ }^{55}$. El encendido del fuego nos dice aquí mucho ya no de la formalidad que adquiere la presencia del nuevo poseedor del dominio sino de una de las actividades cotidianas de la Galicia medieval, así como de su mentalidad colectiva. El fuego traía sentido de seguridad, de hogar propio en el que temperatura y luz están controladas frente

51 «Los pies como elemento indicador de la posesión corporal del señorío». Quintanilla Raso, «El orden señorial», p. 858 .

52 ACS, P003, fol. 29v. Como primera atención al paseo y su significación en las tomas de posesión cf. Beceiro Pita, «La imagen del poder feudal», p. 161. De manera más sencilla, el sentido parece ser el mismo en la toma de posesión por Gonzalo Díaz, vecino de Compostela, de las casas que aforaba del Cabildo en la ciudad a 11 de octubre de 1449. La formalidad es mucho más simple sobre un mero reconocimiento público: o sobre dito Gonçaluo Dias foy dentro aas sobre ditas casas et entrou dentro en elas disendo que as reçebia et reçebeo et o jur et posison delas paçificamente et sen enbargo algun. ACS, CF 26, Tumbo G, fol. 25v.

53 ACS, S 21/31-2。.

54 ACS, S 21/33-2०.

55 ACS, S 16/35. 
LAS FORMAS DEL PODER EN LA FEUDALIDAD TARDÍA. LAS TOMAS DE POSESIÓN EN EL SEÑORÍO DE LA IGLESIA DE SANTIAGO DE COMPOSTELA DURANTE EL SIGLO XV: DOMINIO, GESTO... XOSÉ M. SÁNCHEZ SÁNCHEZ

a la intemperie e incertidumbre de la Naturaleza y a la oscuridad. El fuego lo enciende el que toma el lugar, el que lo posee y decide cuándo ha de calentarse o iluminarse. La significación es más amplia y alcanza a la vida cotidiana en su generalidad, pues «la vida giraba en torno al hogar y la lumbre encendida que era también el símbolo de la casa habitada ${ }^{56}$. La posesión es aquí la del lugar habitable, más allá del propio espacio físico ${ }^{57}$, y es por voluntad del poseedor que ahora temperatura y luminosidad se modulan.

En aquellos casos en que la posesión incluye finca, casal o propiedades circundantes, cobra también mayor presencia la toma en las manos de los elementos materiales relacionados. En 1473 el canónigo compostelano Juan París toma posesión del lugar de Corexo, en Santa María de Marrozos, con casa derruida y casal, de lo cual se posesiona por andamento de pees, et tomou en sua maao da pedra et terra dos formaas das casas do dito casal et medeo que estauan hermos et derrocadas, et tomou das follas et pinnas das aruores et pinneiros $^{58}$. La actividad física es ineludible: el recorrido a pie es de nuevo forma de posesión, de recorrido por el poseedor, a su voluntad y antojo, y aprehensión de materiales, por mucho que se trate de un bien derruido. A ello se añade lo simbólico del fruto de los árboles como elemento alegórico en representación de lo natural. Es la toma de la parte por el todo, dando lugar a un proceso gestual establecido que tiene como fin último el reconocimiento público ${ }^{59}$. Cuando el canónigo Pedro Fernández de Tribaldes toma posesión en 12 de junio de 1415 de las propiedades recibidas por donación a la institución capitular en la feligresía de Santa María de Liripio, se ofrecen los gestos fundamentales en el traspaso con los donantes:

En punto tomaron duas chaues, huna delas de huna casa et outra de huun çeleiro, et çarraron as portas da dita casa et çeleiro et sayronse fora dellas. Et poseron as ditas chaues enna maao do dito Pero Fernandes. Et deronllas en poder et posisson con huna maada de palla da cubertura das ditas casa et huna presa de terra da dita herdade ${ }^{60}$.

Los antiguos poseedores cierran las puertas como acto último, límite hacia el exterior, salen de la propiedad y transmiten la posesión sobre la transmisión de objetos y elementos simbólicos: las llaves, paja del tejado y tierra del suelo. El lugar y la habitación son recogidos y aceptados por el nuevo propietario a través de la recepción de símbolos que vienen de antiguo. Es lo que G. de Valdeavellano definía como «símbolo de objeto»

56 Asenjo GonzÁlez, María. «El ritmo de la comunidad: vivir en la ciudad, las artes y los oficios en la Corona de Castilla». En Iglesia Duarte, José Ignacio (coord.). La vida cotidiana en la Edad Media: VIII Semana de Estudios Medievales: Nájera, del 4 al 8 de agosto de 1997. Logroño: Instituto de Estudios Riojanos, 1998, p. 189. Cf. Ariès, Philippe y Duby, Georges. Historia de la vida privada. 4, El individuo en la Europa feudal. Madrid: Taurus, 1991, pp. 156 y ss.

57 Puñal Fernández, «Análisis documental», p. 135.

58 ACS, S 19/19.

59 «Asir una rama de árbol, coger o comer los frutos, poner un poco de tierra en la palma de la mano, realizar surcos con el arado, arrancar yerbas del campo, poner en marcha el molino, quebrar tejas de un edificio, modificar las piedras que marcan los linderos, beber agua de la fuente constituyen los principales exponentes de la propiedad territorial y los que mejor expresan ese principio común a la mayoría de los signos icónicos de la parte por el todo». Beceiro PitA, «El escrito, la palabra», p. 76.

60 ACS, CF 29, Tumbo E, fol. 10v. 
LAS FORMAS DEL PODER EN LA FEUDALIDAD TARDÍA. LAS TOMAS DE POSESIÓN EN EL SEÑORÍO 144 DE LA IGLESIA DE SANTIAGO DE COMPOSTELA DURANTE EL SIGLO XV: DOMINIO, GESTO...

en el proceso de enfeudación clásica: «el vasallo conservaba en su poder el objeto simbólico que el señor le entregaba y que simbolizaba lo que era objeto del 'feudo', como una rama, un poco de tierra o de hierba cuando se trataba de bienes rústicos ${ }^{61}$. El documento continúa con una especificación todavía más clara: por la tradiçon das ditas chaues et manugada de terra poynan et apoderauan et sentauan en real, actual, corporal posisson ${ }^{62}$. La referencia a la "tradición» remite sin duda a algo asentado, usual y comprendido por el marco social en general. Este proceso no es algo que sea necesario explicar: la mentalidad colectiva lo tiene perfectamente asumido, con menciones similares en los siglos anterio$\operatorname{res}^{63}$ y alcanzando el siglo XV en total vigencia. Las llaves, de hecho, centran algunas de las muestras de mayor pervivencia en cuanto a la asociación simbólica de una atribución o derecho desde antiguo ${ }^{64}$.

En la posesión de 1415 en Tribaldes viene luego la aceptación, especificada en la propia recepción y como culminación de un acto jurídico válido: $o$ dito Pero Fernandes, en nome do dito cabidoo et para el, disso que por los ditos actos et comprehension que fazia das ditas chaues et terra et inspection de ollos que assy resçebia a posesion ${ }^{65}$.

La posesión que la monja Mayor Fernández y Catalina Pérez toman en 28 de abril de 1450 sobre el lugar de Tribaldes, feligresía de Santa María de Baamonde, amplía lo visto. Tras solventar un pleito sobre el término, el mayordomo:

foy logo a huun paaço tellado et abreu a porta del et diso a as sobre ditas Catalina Peres e Mayor Fernandez que entrasen enno dito paaço, et elas entraron dentro del por mandado do dito mayordomo, et eso mesmo en huna casa pallaça que esta junta con el. Et tomou as chaues das ditas casas a Juan Batallan, labrador morador enno dito lugar, et douas et entregoas a as ditas Mayor Fernandes et Catalina Peres en suas maaos, et dandolles mays et poendo en suas maaos da rama das vinnas et das aruores et pedras et terra et brua, en lugar de posison vel que sy de todas las herdades et plantados et viinas que o dito seu yrmaao avia enno dito lugar et de que era poseedor. Et as ditas Catalina Peres et Mayor Fernandes asy as reçeberon et çarraron et fecharon as portas das ditas casas por sy mesmas et se deron por apoderadas enna dita posison sen embargo algun ${ }^{66}$.

El cambio se hace evidente en la entrega de las llaves como elemento material y casi alegórico. Su papel es fundamental, pues toman el protagonismo simbólico en el caso de los inmuebles -tiene su correlación, como veremos, en los elementos naturales para el caso de posesión sobre espacios productivos-, de manera que su posesión denota ejercicio del dominio. Es uno de los «signos icónicos» que Isabel Beceiro definía en cuanto a las

61 García de Valdeavellano, Curso de Historia, p. 371.

62 ACS, CF 29, Tumbo E, fol. 11r.

63 En la posesión, por ejemplo, que Pedro Louzón hace en 1364 fechara huna porta das ditas casas con huna chave de ferro con dous clauos. ACS, S20/14.

64 En 1259-67 el sínodo compostelano, con el prelado compostelano Juan Arias a la cabeza, condenaba a aquel que recibiese iglesias, o sus llaves o casas, de manos de los laicos. El núcleo es el de la posesión, pero la transmisión de la llave por un laico implicaba igualmente forma pública del poder. GARCíA y GARCÍA, Antonio (ed.). Synodicon Hispanum. I, Galicia. Madrid: Biblioteca de Autores Cristianos, 1981, p. 270.

65 ACS, CF 29, Tumbo E, fol. 11r.

66 ACS, S $19 / 7$. 
LAS FORMAS DEL PODER EN LA FEUDALIDAD TARDÍA. LAS TOMAS DE POSESIÓN EN EL SEÑORÍO DE LA IGLESIA DE SANTIAGO DE COMPOSTELA DURANTE EL SIGLO XV: DOMINIO, GESTO... XOSÉ M. SÁNCHEZ SÁNCHEZ

ciudades en su conjunto; su posesión trae la consecuencia de posesión del bien, en una representación de la parte por el todo y en herencia de la traditio romana que alcanza estos tiempos finales de la Edad Media ${ }^{67}$.

A partir de aquí esta posesión de 1450 ve un añadido bastante usual: la cesión del usufructo, del dominio útil y de uso ${ }^{68}$. Logo esta ora poseron et leyxaron de sua maao, jur et posison enno dito paaço et casas et herdades a Juan Batallan, labrador, et sua moller Costança, os quaes diseron et se reconosçeron que ficauan por eles et en seu nome, et de sua maao, jur et posison ${ }^{69}$. El disfrute del espacio se delega con temporalidad reducida y dependencia marcada en una segunda línea que a través de la gestualidad reconoce la delegación, en este caso de viva voz. La transmisión se fija en dos momentos: en la exclusividad de decidir quién vive en el interior, sacando fuera al anterior morador y cerrando la puerta; y en el reconocimiento de ese morador, una vez readmitido, de que la residencia y estancia se hace no por sí mismo sino en la delegación de un derecho que le hace el nuevo poseedor. Tomás Puñal definía la formalidad y gestualidad de estos casos: apertura de puertas, pregunta y aceptación oral del inquilino en su voluntad de vivir en el inmueble, con compromiso de pagar la renta correspondiente y recibir al propietario; toma de la mano al inquilino; e introducción en la casa ${ }^{70}$. El proceso en el señorío compostelano del siglo Xv parece ajustarse bastante a este esquema, aunque pueda variar el orden o repetir el reconocimiento oral. En 31 de mayo de 1406 el cabildo compostelano afora una casa al escribano Pedro Alfonso y su esposa, Marina Alfonso, en la calle compostelana Rúa do Vilar, especificando en primer término las condiciones de la cesión en temporalidad y renta. La cesión no es absoluta ni del dominio directo, pues no habrá una capacidad libre y completa de actuación sino limitada tanto en el tiempo como en las posibilidades: el tomador del foro no podrá vender el bien, simplemente porque no es suyo. Acto seguido el escribano entrou dentro enna ditas casas et poso fora delas a Afonso Moleiro et sua moller, Maria Peres, et Moor Eanes, moller de Martin Eanes, çapateiro, que morauan ennas ditas ${\operatorname{cas} a s^{71}}^{7}$; es la voluntad del nuevo detentador del dominio útil, en su capacidad de hacer. Y asi apoderado ennas ditas casas et teendoas reçebidas tornou a elas de sua maao et jur et posision aos ditos Pero Moleiro et sua moller Maria Peres et Moor Eanes, et leixoos en elas de sua maao et jur et posison. Et elles asi o diseron que en ellas ficauan por lo dito Pero Afonso ${ }^{72}$. Son nuevos usufructuarios del derecho de uso que quedan ahora en el inmueble sobre la delegación de aquel que había tomado posesión en primer término.

67 Beceiro Pita, «El escrito, la palabra», p. 73. En otros ámbitos o posesiones otros objetos tomarían este mismo papel simbólico; es el caso de las varas de justicia y su traspaso en la toma de posesión del cargo por los alcaldes. Beceiro Pita, «La imagen del poder feudal», p. 160. Especial peso simbólico tiene, por ejemplo, en la posesión que estudiaba ya Rodríguez Llopis para la tierra de Alarcón en 1445. Rodríguez Llopis, «Las tomas de posesión bajomedievales», p. 351.

68 Tomás Puñal había definido ya el proceso para el conjunto castellano y no hay demasiada variación, diferenciando de manera genérica «el acto de trasmisión y posesión de la propiedad realizado entre comprador y vendedor, del de traspaso de usufructo entre nuevo propietario e inquilino». Puñal Fernández, «Análisis documental», p. 128.

69 ACS, S 19/7.

70 Ibidem, p. 129.

71 ACS, CF 29, Tumbo E, fol. 21r.

72 ACS, CF 29, Tumbo E, fol. 21r. 
LAS FORMAS DEL PODER EN LA FEUDALIDAD TARDÍA. LAS TOMAS DE POSESIÓN EN EL SEÑORÍO DE LA IGLESIA DE SANTIAGO DE COMPOSTELA DURANTE EL SIGLO XV: DOMINIO, GESTO... XOSÉ M. SÁNCHEZ SÁNCHEZ

Este dominio útil es un recurso económico perfectamente enajenable de nuevo a cambio de renta dando lugar a una toma de posesión bien similar a la posesión del dominio directo y que sigue lo conocido. En 28 de marzo de 1465 Juan de Portomarín, zapatero, toma posesión de una casa en la ciudad de Santiago como voz en su arriendo, es decir, en el uso y disfrute, no en la propiedad. Pero inmediatamente lo subarrienda a Suero de Bardaos:

tomou o jur e posison da dita casa andando por ela e poendo de fora dela ao dito Suero de Bardaaos que en ela moraua, çerrando a porta da rua da dita casa e despoys ha abrindo e poendo dentro dela de sua maao, jur e posison ao dito Suero de Bardaaos, o qual confesou que ficaua de sua maao, jur e posison, e non por el [...] nen por outra persona alguna ${ }^{73}$.

Despiezando otros ejemplos contemporáneos se confirma la pauta de rito, gestos y significación. Resulta quizá más gráfica la toma de posesión de Robín Francés y su esposa Constanza González de la casa que les afora el monasterio de San Paio de Antealtares en 15 de julio de 1465. Desarrollan el proceso entrando de dentro das ditas casas e paseandose enno alto e baixo delas e poendose fora delas a Costança Fernandes Benveente, çerrando as portas delas e poendo dentro delas de sua maao, jur e posison a dita Costança Fernandes, a qual confesou que ficaua e ficou enna sitas casa de maao, jur e posison do dito Robyn e sua moller $^{74}$; esa permanencia por resulta indicativa. En 3 de abril de 1473 Pedro Fernández, criado del arzobispo Alonso de Fonseca II, toma posesión del lugar de Tribaldes por mandato en carta arzobispal. El mayordomo del lugar, Juan de Pazos, tomoo por la maao et meteo dentro da casa e paaço tellado do dito lugar ao dito Pero Fernandes, et tomou as chaues da dita casa e paaço e dou ha o dito Pero Fernandes e diso que lle daua e dou a posison de todo o dito lugar contiudo enna dita carta ${ }^{75}$. Una vez recibida ejerce ya su voluntad por el contacto físico: o dito Pero Fernandes entrou enna dita casa e tomou as chaues dela e andou por ela e por lo dito lugar e çerrou as portas da dita casa. Et diso que como tomana e tomou, reçebia e reçebeu a dita posison ${ }^{76}$. Y deja luego en su nombre como apoderado a Alfonso Batallán sobre gestualidad conocida: tomoo por la maao e meteo dentro da dita casa e paaço $e$ doulle e entregou as chaues da dita casa e o dito Alfonso Batallan reçebeo as ditas chaues e diso que quedaua enno dito lugar e casa e paaço por lo dito Pero Fernandes. Et de aqui endeante era e estaua prestes de teer o dito lugar e posison del por lo dito Pero Fernandes ${ }^{77}$. Poco después, en 26 de abril del mismo año, el canónigo Juan París toma posesión de las casas en que vivía Mayor Batallán, también en Tribaldes. Recibe casas y aledaños del lugar et çerrou et fechou as portas delas et botou fora a a dita Moor Batallaan, moller do dito Afonso Batallan; una vez entrado en el lugar tomou das follas dela et das aruores ao dito lugar perteesçentes et da terra et pedra et das ditas herdades, et diso que tomana et resçebia et tomou et resçebeo a dita posyson ${ }^{78}$. La apertura y cierre de puertas centra la nueva condición, en el

\footnotetext{
73 ACS, P003, fol. 266v.

74 ACS, P003, fol. 288v.

75 ACS, S 19/24.

76 ACS, S 19/24.

77 ACS, S 19/24.

78 ACS, S 19/19.
} 
LAS FORMAS DEL PODER EN LA FEUDALIDAD TARDÍA. LAS TOMAS DE POSESIÓN EN EL SEÑORÍO DE LA IGLESIA DE SANTIAGO DE COMPOSTELA DURANTE EL SIGLO XV: DOMINIO, GESTO... XOSÉ M. SÁNCHEZ SÁNCHEZ

ejercicio de la voluntad del nuevo poseedor que ahora, haciendo a su antojo, permite o bloquea el acceso. Pone fuera del espacio a los antiguos moradores, dejando clara su condición preeminente y coge lo que es suyo: la tierra, las hojas, las piedras... los elementos naturales, en definitiva. Todo da paso a la delegación del dominio útil: fezo pregunta a a dita Mayor Batallaan se queria as chanes das ditas casas et paaços et teer o dito lugar con suas casas, vinnas et herdades et aruores por el et en seu nome, et lle daria et entregaria as ditas chaues das ditas casas et paaços ${ }^{79}$, con respuesta específica, pues la interpelada afirma su voluntad de teer et poseer o dito lugar por el et en seu nome et reçeber de sua maao as ditas chaues et llas daria et entregaria cada et quando que llas pedise et demandase et lle leixaria et desenbargaria a posyson do dito lugar et a non daria a ningun outro ${ }^{80}$. La reafirmación oral pública en esta voluntad de cambio certifica la delegación de la capacidad útil sobre el espacio; primero había sido poseída en su totalidad por el nuevo tenente y ahora se delegaba parcialmente este desgajado dominio útil. Tiene especial significación de ese «tener por», en un reconocimiento implícito del mandato casi feudovasallático en la gestión. Y finaliza el proceso con la materialización: $o$ dito Juan Paris dou et entregou logo as chaues do dito lugar a a dita Mayor Batallan et desfechou as portas das ditas casas et paaços et poso et meteo dentro das ditas casas a a dita Mayor Batalla ${ }^{81}$, tras lo cual Juan París pide testimonio notarial. Mayor Batallán, recibidas las llaves, las usa y abre las puertas pues la delegación se ha completado.

En todo el ritual se identifican, junto a los objetos simbólicos, la mano y la palabra como elementos tradicionales y de origen antiguo. Las manos se revelan como órgano y elemento fundamental ${ }^{82}$. Hay vínculo claro con la larga tradición de la gestualidad feudal, desde la inmixtio manuum en el contrato feudovasallático y las manos del vasallo entre las del señor. Ahora el poseedor toma por la mano a aquel en quien delega y lo introduce en el inmueble dando a entender que el acceso se produce con su autorización y connivencia. Dentro le entrega las llaves, en un proceso que se cierra con el reconocimiento público de que ahora tiene la casa por el tomador. A mayores de lo citado, resulta clarificadora la toma de posesión que en 15 de junio de 1457 había hecho Juan Fernández Durán, como procurador de la capilla de San Bieito de Campo, de varias casas en la calle compostelana de Abril Ares y en las cuales vivía el escribano Pedro de Sarela. Tras declarar su recepción por donación y testamento

çarrou as portas delas e fezo pergunta a Maria Ramos, moller do dito Pedro de Sarela, que presente estava, se queria ficar enno dito terço das ditas casas por e en nome da dita capela de San Byeyto. E a dita Maria Ramos diso que ela, sendo çerta dos ditos contratos e doaçoos [...] querya ficar enno dito terço entregamente das ditas casa e enna posyson del por e en nome da dita capela. E o dito Juan Fernandes Duran tomou por la maao a a

79 ACS, S 19/19.

$80 \quad$ ACS, S $19 / 19$.

81 ACS, S $19 / 19$.

82 La mano se constituía ya desde hacía tiempo en elemento fundamental como vehículo de transmisión simbólica. Cf. Miguélez Cavero, Alicia. «El poder gestual de la mano en la sociedad medieval y su reflejo en la iconografía de los siglos del románico en la Península Ibérica». Medievalismo, 2010, vol. 20, pp. $125-147$ 
LAS FORMAS DEL PODER EN LA FEUDALIDAD TARDÍA. LAS TOMAS DE POSESIÓN EN EL SEÑORÍO DE LA IGLESIA DE SANTIAGO DE COMPOSTELA DURANTE EL SIGLO XV: DOMINIO, GESTO... XOSÉ M. SÁNCHEZ SÁNCHEZ

dita Maria Ramos e a poso dentro enna dita casa e lle dou as chaues das portas dela, a qual dita Maria Ramos diso que conosçia e conosçeu que ficava enna terça parte das ditas casas por e en nomme da dita capela ${ }^{83}$.

La declaración pública tiene el sentido de vinculación en la posesión y en la delegación que el detentador del dominio directo, la capellanía, hace del dominio útil. No es ajena la palabra a las tomas de posesión, sobre su vinculación al gesto en «la función de desvelar su significado, de tal manera que lo diferencie claramente de otros idénticos, pero no formalizados y que, por tanto, pertenecen al campo de lo particular y no del mundo del signo y el símbolo» ${ }^{84}$. De nuevo la clave está en el por; la preposición implica la delegación del derecho, en una forma que venía de antiguo sobre la base de los vínculos personales de un hombre o vasallo «por» su señor. La posesión se transmite de nuevo, pero no se disfruta per se, sino por e en nomme de la institución. Tras la pregunta y la confirmación, las llaves cobran una vez más especial sentido como símbolo de ese dominio útil y derecho de disfrute. La posesión de 1482 del casal de Donego por el racionero Juan Calviño finaliza también con la delegación en un usufructuario indirecto sobre la misma declaración pública y ritualidad definidas con un reconocimiento público en forma de frases que acompañan al gesto: logo fizo pregunta a a dita Moor Fernández se queria beuir por el enno dito casal, a lo que ela diso que sy ${ }^{85}$.

El procedimiento en su generalidad se mantiene, al menos en el espacio señorial compostelano, hasta los estertores del período sobre la misma formalidad y ejes: en lo práctico la voluntad del nuevo poseedor que, sobre el recorrido de estancias, contacto físico y/o apertura y cierre de puertas, desarrolla su voluntad sobre el inmueble; y en lo simbólico las llaves, principalmente, como materialización de dicha voluntad y cuyo cambio de manos y posesión ejemplifica la tenencia del bien. En 11 de mayo de 1498, los canónigos Gómez Méndez y Fernán Domínguez toman posesión como procuradores de la institución catedralicia de varias casas en la ciudad e entraron dentro das camaras et sobrados das ditas casas desfechando as portas delas et abrindoas et çerrandoas sobre sy, apoderandose et tomando o jur et posison das ditas casas, alto et vaixo delas, e entrando dentro do dito curral, ortas et caualariça das ditas casas andando por elas et abrindo as portas delas et çerrandoas, dizendo que tomauan et reçebian para a dita mesa capitular a dita posison ${ }^{86}$.

Hasta aquí casas y espacios de habitación con su entorno relacionado. Pero las formas de la feudalidad tardía tienen también su configuración simbólica en las tomas de posesión referidas a espacios productivos: tanto propiedades, en lo relativamente extenso y unitario, como unidades de producción. Aquí toman forma una serie de unidades de amplitud relativamente considerable e indeterminadas, con denominaciones genéricas como lugar, rial, cortiña, y orientadas a la consecución de recursos incluyendo plantas,

83 Fernández de Viana y Vieites, El tumbillo de San Bieito, doc. 39, p. 105.

84 Beceiro Pita, «El escrito, la palabra», p. 69. El recurso a la oralidad, esfera complementaria a la gestualidad, se documenta igualmente en actos feudales como el pleito-homenaje sobre una aceptación verbal de claro matiz político. BeCEIRo PitA, «La imagen del poder feudal», p. 158.

85 ACS, S 16/35. El mismo proceso se sigue en la toma de posesión del lugar de Forcarelos, en 19 de abril, que se incluye también en este documento.

86 ACS, CF 27, Tumbo F, fol. 132v. 
LAS FORMAS DEL PODER EN LA FEUDALIDAD TARDÍA. LAS TOMAS DE POSESIÓN EN EL SEÑORÍO DE LA IGLESIA DE SANTIAGO DE COMPOSTELA DURANTE EL SIGLO XV: DOMINIO, GESTO... XOSÉ M. SÁNCHEZ SÁNCHEZ

árboles frutales, tierras de labor, espacios de recolección, pastos... Sea el conjunto que fuere, la marca gestual de la transmisión de dominios es la de la parte por el todo a través de la realización de una actividad simbólica y puntual que da a entender el disfrute de un nuevo poseedor sobre el conjunto. Se mantienen aquí los dos elementos que ya hemos visto en cuanto a los inmuebles: el recorrido, como forma de aposentamiento; y la aprehensión de un elemento material, antes las llaves ahora elementos naturales ${ }^{87}$.

La toma de posesión del mercader Pedro Leiteiro sobre el lugar de Loxo, en 25 de enero de 1418, merece cierto detenimiento, pues su medida descripción permite objetivar el proceso:

Estando enno dito lugar [...] disso que por rason que el auia conprado por si et por la dita sua moller çertos quinoes do dito lugar de Lojo Menor [...] segundo mostrou por duas cartas de conpla (sic) [...] por ende que el por si et en nome da dita sua moller que entraua et reçebia et entrou et reçebeu a jur de paz et sen enbargo alguun os ditos quinoes [...] et tomou rama et terra et pedra et colmo en lugar de jur et possison. Et leyxou ennas casas do dito lugar de sua maao et jur et posison a Roy de Lojo Menor, laurador que en el moraua, o qual Roy de Lojo Menor, ficou ennos ditos quinoes do dito lugar de maao et jur et posison do dito Pedro Leiteiro, et prometeu de lle recodir d'aqui endeante con as rendas et nouidades deles. Et desto en conmo passou o dito Pedro Leiteiro pedio testemoyo ${ }^{88}$.

El procedimiento se inicia con la declaración pública de la venta realizada y adquisición por el nuevo poseedor; cobra aquí peso la materialidad del documento escrito, la carta de venta que es mostrada de manera pública. En función de ella el nuevo tenente entra en su propiedad, y en disfrute de su dominio directo toma elementos de ella -una vez más tierra, rama y piedra en representación de todo el espacio-. Se desgaja luego el dominio útil, que se deriva y deja en manos de un tercero, el cual se compromete al trabajo directo sobre el mismo y al devengo de la renta correspondiente. Y se finaliza con una nueva certificación documental que remata el proceso. Todo el conjunto es uniforme con respecto a las tomas de posesión de inmuebles ya consideradas, sobre un formalismo ritual de relativa generalidad.

El eje es, de nuevo, el ejercicio de la voluntad por el nuevo poseedor. El recorrido de los espacios, a modo de simple paseo, materializa el examen del bien que ahora se posee, y el contacto físico con los elementos naturales da forma a su potestad. Entra y sale, coge y deja, toma y suelta, corta y tira aquello que ahora es suyo. Cuando el clérigo Juan González de Asados toma posesión de varias propiedades rurales en las feligresías de Santa María de Asados y Santa Comba de Rianxo, en 13 de febrero de 1417, en presencia del notario derramou et podou todas las aruores que estaban enno dito rial ${ }^{89}$. En 2 de julio de 1473 aquel Pedro Fernández, criado del prelado compostelano Alonso de Fonseca II, toma posesión del lugar de Corexo que había comprado a su hermana María Álvarez. Para ello:

87 Ahora «el acto se manifiesta a través de una serie de elementos relacionados con su utilización y aprovechamiento». PUÑal FernándeZ, «Análisis documental», p. 133.

88 ACS, S21/15.

89 ACS, S20/40. 
LAS FORMAS DEL PODER EN LA FEUDALIDAD TARDÍA. LAS TOMAS DE POSESIÓN EN EL SEÑORÍO DE LA IGLESIA DE SANTIAGO DE COMPOSTELA DURANTE EL SIGLO XV: DOMINIO, GESTO...

tomaua e tomou o jur e posison e propiedade das sobreditas herdades, casas e chantados, entrado dentro dos pardineiros, que foron casas que perteesçen a a dita Maria Aluares e a el por la sobre dita conpra, e sayndo deles a jur de pas e sen contradita alguna que ende lle fose feyto, tomando dos ditos pardinneiros pedra e terra e rama das aruores segund custume ${ }^{90}$.

Lo simbólico se construye sobre un gesto en que tierra, rama y piedra dan forma a lo material para fijar en ellos la representación de todo un conjunto territorial que era demasiado extenso para ser recorrido. Por ello se declara que esta finca hera cabeça das ditas herdades que de aly tomaua e tomou e aprendia e aprendeu o jur e posison e propiedad de todas las outras herdades e chantados ${ }^{91}$.

El proceso formal parece menos elaborado en estos casos y de menor recorrido, quizá por ser precisamente unidades más extensas que un inmueble con huerta e imposibles de examinar. Cuando en 13 de junio de 1402 el capellán Gómez Pérez tomaba posesión del casal de Vilińo, en Santa Baia de Ozón, el procedimiento reflejado en el documento notarial detalla bien poco: por vertude et poder da dita carta de venda que entraua et entrou per sy meesme, et resçebeu para sy por terra et pedra et ferro, colmo et madeira, o dito casal et casas et herdades et chantados de Vilinno ${ }^{92}$. Sobre los elementos que cogía en la mano el nuevo poseedor se edificaba en lo simbólico la posesión de todo el conjunto, más allá de lo legal ya especificado en la carta de venta. A partir de aquí el disfrute, al igual que en el caso de inmuebles y sus adyacentes, era el del dominio directo, sobre la capacidad de desgajar y delegar el dominio útil. El reconocimiento se antoja fundamental y en este último caso frontaua et frontou logo a Lourenço da Riba, que presente estaua, que tiina arrendado o dito casal, casas et herdades, [... que ficase por el ennas ditas casas, casal et herdades, et lle rendese daqui endeante con as rendas et froitos et nouidades del, et o dito Lourenço da Riba diso que asi ficaua et fiquo de maao et jur et posison do dito Gomes Peres et por el enno dito casal de Vilinno ${ }^{33}$. Es el reconocimiento público de un disfrute que nuevamente no es propio sino por un tercero, siguiendo el antiguo camino de la cesión señorial y feudal de derechos.

En ocasiones la cesión y derivación del dominio útil a cambio de renta cobra importancia incluso por encima de la propia posesión. Esto tiene especial sentido en los espacios productivos, orientados principalmente al trabajo directo y de sentido rentista. El 31 de julio de 1428 el canónigo compostelano Jácome Sánchez toma posesión en nombre de la institución capitular del casal de Marrozos sin mayor proceso gestual, recorrido o aprehensión de elementos materiales, pero requerindo a Juan Peres de Marroços, morador enno dito lugar, que presente estaua et que lauraua çertas herdades do dito casal, que ficase en el de maao et jur et posison do dito cabidoo, a lo cual Juan Pérez accede y se compromete al pago de renta correspondiente ${ }^{94}$.

Si bien se trata de propiedades eminentemente agrarias, en ocasiones incluyen algún inmueble o casas, conformando unidades de producción al estilo de aquellos casales y propiedades urbanas con terruño para el cultivo, aunque ahora de una amplitud

90 ACS, S19/23.

91 ACS, S19/23.

92 ACS, CF 29, Tumbo E, fol. 22v.

93 ACS, CF 29, Tumbo E, fol. 22v.

94 ACS, S22/18. Un Afonso Eanes hace lo propio en el mismo documento para el casal de Aldrei. 
LAS FORMAS DEL PODER EN LA FEUDALIDAD TARDÍA. LAS TOMAS DE POSESIÓN EN EL SEÑORÍO DE LA IGLESIA DE SANTIAGO DE COMPOSTELA DURANTE EL SIGLO XV: DOMINIO, GESTO... XOSÉ M. SÁNCHEZ SÁNCHEZ

considerablemente mayor. En ambos casos la unidad de habitación está asociada al espacio productivo y la toma de posesión se realiza sobre ambas. En 23 de octubre de 1494 el escribano Fortián García, luego de presentarse en el lugar y aldea de Vilabuide y hacer público el traspaso, toma posesión del mismo, para lo cual entrou en vna casa en que soya morar Martin de Rial, defunto, et çerrou as portas da dita casa sobre sy. Acto seguido cogió en sus manos colmo e terra que dentro da dita casa achou, dezendo que asy tomana et tomou a posesyon ${ }^{95}$. Esta última frase explica a la perfección el sentido simbólico de la materialidad en las manos del nuevo poseedor. Igualmente, tras aquella posesión que hacía Robín Francés de su casa en Compostela, en 11 de junio de 1465, logo entrou enna dita cortinna e diseron que asy mesmo a reçebian e reçeberon andando por ela de pees, tomando das eruas e terra e pedras da dita cortinna en lugar de posyson ${ }^{96}$. Otra vez elementos naturales que toman la parte por el todo y representan de manera simbólica el lugar, aquí en hierba, tierra y piedra, explicitando que se les coge como forma de posesión del espacio.

Finalmente se mantiene el mismo esquema para otras unidades productivas más allá de las hortofrutícolas. Cuando en 1418 se toma posesión de un molino ubicado en Fervenza do Outeiro, feligresía de Santa María de Asados, el receptor declara que reçebia o dito moyno et chaue por las maneiras e condiçoes sobre ditas. Et logo o fazia moer et çerraua a porta del con a dita chaue ${ }^{97}$. El notario presente certifica que presente fuy y et vy moer o dito moyno farinna de millo et estar leuantado de paredes et coberto de colmo. Si con algún inmueble hemos visto encender el fuego, y en otros espacios podar los árboles, la molienda es aquí el ejercicio de la actividad cotidiana del bien que se posesiona y su desempeño por el nuevo detentador es la evidencia de una nueva autoridad que ejerce su voluntad en y sobre el mismo.

Gesto y símbolo sobre el dominio toman forma en un proceso ritual de clara significación tardo-feudal que en el territorio señorial compostelano del siglo Xv aprehende, modela y devuelve de manera pública concepciones todavía vigentes en cuanto al disfrute de derechos feudales. Actos (destacando paseos, aperturas y cierres, fuego y moliendas), contactos (en lo simbólico de la parte por el todo, principalmente en los espacios productivos) y objetos (con especial significación de las llaves), ajustan un ejercicio de gestualidad medida que alcanza el final del período medieval en el señorío de la iglesia compostelana y permite medir pervivencias, cambios e influencia de lo social en la mentalidad colectiva.

\section{REFERENCIAS BIBLIOGRÁFICAS}

Althoff, Gerd; Witthöfт, Christiane y Duthoo, Aurélie. «Les services symboliques entre dignité et contrainte». Annales. Histoire, Sciences Sociales, 2003, vol. 58, n. ${ }^{\circ}$ 6, pp. 1293-1318.

Andrade Cernadas, José Miguel. «Baños, claustros y piedras: una aproximación a los escenarios de las asambleas judiciales en la Galicia altomedieval». Studia Historica. Historia Medieval, 2018, vol. 36, n. ${ }^{\circ}$ 1, pp. 13-30.

95 ACS, S17/29.

96 ACS, P003, fol. 290v.

97 ACS, S20/42. 
LAS FORMAS DEL PODER EN LA FEUDALIDAD TARDÍA. LAS TOMAS DE POSESIÓN EN EL SEÑORÍO DE LA IGLESIA DE SANTIAGO DE COMPOSTELA DURANTE EL SIGLO XV: DOMINIO, GESTO.. XOSÉ M. SÁNCHEZ SÁNCHEZ

Ariès, Philippe y Duby, Georges. Historia de la vida privada. 4, El individuo en la Europa feudal. Madrid: Taurus, 1991.

Asenjo González, María. «El ritmo de la comunidad: vivir en la ciudad, las artes y los oficios en la Corona de Castilla». En Iglesia Duarte, José Ignacio (coord.). La vida cotidiana en la Edad Media: VIII Semana de Estudios Medievales: Nájera, del 4 al 8 de agosto de 1997. Logrońo: Instituto de Estudios Riojanos, 1998, pp. 169-200.

Beceiro Pita, Isabel. «El escrito, la palabra y el gesto en las tomas de posesión señoriales». Studia Historica. Historia Medieval, 1994, vol. 12, pp. 53-82.

Beceiro Pita, Isabel. «La imagen del poder feudal en las tomas de posesión bajomedievales castellanas». Studia Historica. Historia Medieval, 1984, vol. 2, pp. 157-162.

Estepa Díez, Carlos. "Notas sobre el feudalismo castellano en el marco historiográfico general». En Sarasa Sánchez, Esteban y Serrano Martín, Eliseo (eds.). Estudios sobre señorio y feudalismo. Homenaje a Julio Valdeón. Zaragoza: Institución Fernando el Católico, 2010, pp. 77-105.

Fernández de Viana y Vieites, José Ignacio. El tumbillo de San Bieito do Campo (Santiago). Granada: Universidad de Granada, 1995.

García de Valdeavellano, Luis. Curso de Historia de las Instituciones españolas. Madrid: Alianza Editorial, 2. ${ }^{a}$ reimpr., 1986.

García y García, Antonio (ed.). Synodicon Hispanum. I, Galicia. Madrid: Biblioteca de Autores Cristianos, 1981

González Vázquez, Marta. El arzobispo de Santiago: una instancia de poder en la Edad Media (1150-1400). Santiago de Compostela: Seminario de Estudios Gallegos, 1996.

LE Goff, Jacques. "Gestes symboliques dans la vie sociale. Les gestes de la vassalité». En Simboli e simbologia nell'Alto Medioevo. Atti (dal 3 al 9 aprile 1975). Spoleto: Fondazione CISAM, 1976, pp. 679-779.

López Carreira, Anselmo. Documentos do arquivo da catedral de Ourense: (1289-1399). Santiago de Compostela: Consello da Cultura Galega, 2016.

López, Gregorio (ed.). Las Siete Partidas del Sabio Rey don Alonso el nono. Salamanca: Impr. Andrea de Portonariis, 1555.

Martín Prieto, Pablo. «Las tomas de posesión de las villas del infantado de Huete por el condestable Álvaro de Luna en 1442». Anuario de Estudios Medievales, 2013, vol. 43, n. ${ }^{\circ}$, pp. 717-750.

Miceli, Paola Alejandra. «Gestualidad corporal y estructura formular en los rituales de posesión en Castilla (siglo xv)». Calamus. Revista de la Sociedad Argentina de Estudios Medievales, 2019, vol. 3, pp. 38-48.

Miguélez Cavero, Alicia. «El poder gestual de la mano en la sociedad medieval y su reflejo en la iconografía de los siglos del románico en la Península Ibérica». Medievalismo, 2010, vol. 20, pp. 125-147.

Pallares Méndez, María Carmen y Portela Silva, Ermelindo. «De la villa del siglo ix a la aldea del siglo xiIr. Espacio agrario y feudalización en Galicia». Asturiensia Medievalia, 1995-1996, vol. 8, pp. 47-69.

Pérez Rodríguez, Francisco Javier. «Santiago, espacio de poder: la Tierra de Santiago y su evolución (s. XI-Xiv)». En Estepa Díez, Carlos; Martínez Sopena, Pascual y Jular PérezAlfaro, Cristina. El Camino de Santiago. Estudios sobre peregrinación y sociedad. Madrid: Fundación de Investigaciones Marxistas, 2000, pp. 33-76.

Pérez Rodríguez, Francisco Javier. El dominio del cabildo catedral de Santiago de Compostela en la Edad Media (Siglos XII-XV). Santiago de Compostela: Tórculo Artes Gráficas, 1994. 
LAS FORMAS DEL PODER EN LA FEUDALIDAD TARDÍA. LAS TOMAS DE POSESIÓN EN EL SEÑORÍO DE LA IGLESIA DE SANTIAGO DE COMPOSTELA DURANTE EL SIGLO XV: DOMINIO, GESTO... XOSÉ M. SÁNCHEZ SÁNCHEZ

Portela Silva, Ermelindo. "La articulación de la sociedad feudal en Galicia». En En torno al feudalismo hispánico. I Congreso de Estudios Medievales. Ávila: Fundación Sánchez-Albornoz, 1989, pp. 331-340.

Portela Silva, Ermelindo y Pallares Méndez, María del Carmen. De Galicia en la Edad Media: sociedad, espacio y poder. Santiago de Compostela: Consellería de Relacions Institucionais e Portavoz do Goberno, 1993.

Portela Silva, María José. Documentos da catedral de Lugo, século XIV. Santiago de Compostela: Consello da Cultura Galega, 2007.

Puñal Fernández, Tomás. "Análisis documental de los rituales de posesión en la Baja Edad Media». Espacio, Tiempo y Forma. Serie III, Historia Medieval, 2002, vol. 15, pp. 113-148.

Quintanilla Raso, M. ${ }^{a}$ Concepción. «El orden señorial y su representación simbólica: ritualidad y ceremonia en Castilla a fines de la Edad Media». Anuario de Estudios Medievales, 1999, vol. 29 , pp. 843-873.

Ríos Rodríguez, María Luz. «El valor de las escrituras: resolución de conflictos entre señores y campesinos en la Galicia bajomedieval». Edad Media. Revista de Historia, 2010, vol. 11, pp. 151-171.

Ríos Rodríguez, María Luz. Relaciones contractuales agrarias en la Galicia medieval: los orígenes del foro (1150-1350). Santiago de Compostela: Universidade de Santiago de Compostela, 1991.

Rodríguez Llopis, Miguel. «Las tomas de posesión bajomedievales y la ideología feudal. La incorporación de la tierra de Alarcón al marquesado de Villena». En Congreso de historia del señorio de Villena. Albacete 23-26 octubre 1986. Albacete: Instituto de Estudios Albacetenses, 1987, pp. 349-356.

SÁnchez SÁnchez, Xosé M. «La fortaleza de Rocha Forte como símbolo del poder político del arzobispado de Santiago de Compostela en la Galicia medieval (siglos XIII-Xv)». Castillos de España. Publicación de la Asociación Española de Amigos de los Castillos, 2012, vol. 164-166, pp. 68-76.

VÁzQUez Bertomeu, Mercedes. «La audiencia arzobispal compostelana en el s. Xv: introducción a su estudio diplomático». Cuadernos de Estudios Gallegos, 1998, vol. 45, pp. 9-29.

VÁzquez Bertomeu, Mercedes. «La escritura y su uso: la mesa arzobispal compostelana a finales del siglo XV». Anuario de Estudios Medievales, 2001, vol. 31, n. ${ }^{\circ}$ 1, pp. 401-428.

VÁzquez Bertomeu, Mercedes. «Santiago en el siglo Xv: protagonistas, usos y espacios de la escritura». Signo. Revista de Historia de la Cultura Escrita, 2004, vol. 13, pp. 7-31.

VÁzquez BeRTOMeu, Mercedes. Notarios, notarias y documentos en Santiago y su tierra en el siglo XV. Sada-A Coruńa: Seminario de Estudos Galegos, 2001. 
